\title{
Influence of Training and Motivation to Satisfaction Worker Exploration Function PT. Pertamina EP Center Jakarta
}

\author{
Ahmad Hidayat Sutawijaya \\ Erly Okta
}

Program Magister Management Faculty Economy \& Business, Universitas Mercu Buana E-mail : sutawijaya_69@hotmail.com and erlyokta@gmail.com

\section{Doi:10.5901/mjss.2015.v6n5s5p9}

\begin{abstract}
The main objective of this research was to determine the influence of job training on job satisfaction, determine the effect of motivation on job satisfaction and to determine the influence of job training and motivation simultaneity on job satisfaction. Type of research used in this research is the explanation (explanatory research) with a quantitative approach. Population that used in this research is 112 people with totally samples 55 respondence. Analysis of the data in this study using descriptive analysis and regression analysis. To analyze the data using SPSS version 20.0 for Windows. Based on the result of regression analysis showed that Job Training variable (X1) has a significant influence on Job Satisfaction (Y) with a value of 0.000. Motivation variable (X2) has a significant influence on Job Satisfaction $(Y)$ with a value of 0.001. Based on Dimension of Correlation Matrix result found that the strongest correlation is Training Materials to Daily Work, this showed that job satisfied at Exploration Division PT Pertamina EP strong influence by electing the appropriate training materials.
\end{abstract}

Keywords: Job Training, Motivation, on Job Satisfaction

\section{Introduction}

As the development of the country's development is influenced by the era of globalization which is the process of international integration that occurs due to the exchange of views the world, products, ideas and other cultural aspects, transport and telecommunications infrastructure advances, including the emergence of the telegraph and the Internet, is a major factor in globalization encourage mutual dependence (interdependence) economic and cultural activity. Efforts to improve the quality of human resources to be in line with the development of the country's development, efforts are ongoing to make changes to suit the demands of the progress of Science and Technology with enriching knowledge relevant to the work of each worker has become imperative so as to achieve the vision and mission organization. One of the programs to obtain quality human resources is a development program worker through training programs.

PT. Pertamina EP (Exploration and Production) is a subsidiary of Pertamina Persero which is a State Owned Enterprise (SOE), PT. Pertamina EP has an organizational structure that is both multi-structural or hybrid which is a combination of matrix structure and functional structure (organizational structure Exploration function can be seen in appendix 1), in which there is some function of which is a function of Exploration who has a duty to seek and find new oil fields. Workers in the Exploration functions almost entirely the same educational background or similar (homogeneous) is the field of Geology and Geophysics ( $G$ \& G). Some constraints in oil and natural gas would be found, this can be due to errors in data interpretation process, operational errors or mistakes made possible because of lack of profound understanding of the science related to exploration activities. Some of the data in the last 5 years shows that productivity tends to stagnate and not achieving the target set by the company as illustrated in the following figure: 


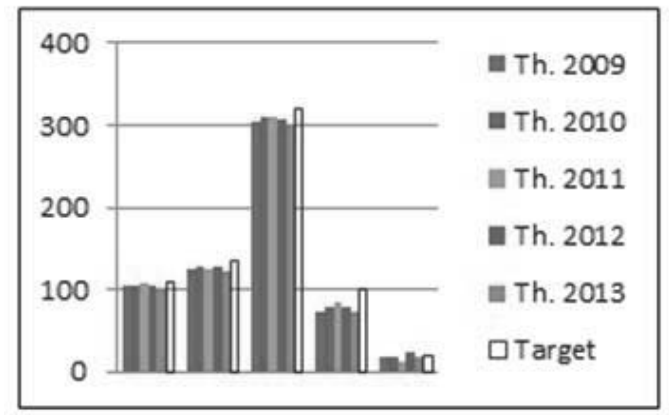

Figure 1. Operational Data Annual Production 2009-2013

Source: Annual Report of PT Pertamina EP (2012 and 2013)

In addition to the large investment costs can result in losses that are not bit if drilling results which do not get the expected results, as happens in the range of 2013 - 2014 in the exploration drilling process has experienced several failures (not found oil and gas / no economical) that cause harm, as can be seen in Table 1 below:

Tabel 1. Exploration Well Drilling Progress period 2014

\begin{tabular}{cccl}
\hline Name Sumur & Zone/Region & Depth $(\mathrm{mD})$ & Description \\
\hline Sumur A & Asset 5 & 2182 & Oil Discovery \\
Sumur B & Asset 3 & 3515 & Oil \& Gas Discovery \\
Sumur C & Asset 5 & 2804 & Less HC Indication \\
Sumur D & Asset 5 & 1205 & HC Indication, non ekonomic \\
Sumur E & Asset 3 & 2036 & Oil \& Gas Discovery \\
Sumur F & Asset 1 & 3435 & Oil \& Gas Discovery \\
Sumur G & Asset 3 & 3600 & Oil \& Gas Discovery \\
Sumur H & Asset 2 & 3527 & On Going \\
Sumur I & Asset 4 & 2713 & On Going \\
Sumur J & Asset 5 & 3001 & On Going \\
Sumur K & Asset 3 & 2318 & On Going \\
Sumur L & Asset 3 & 3415 & On Going \\
\hline
\end{tabular}

Source: Function Eksploration PT. Pertamina EP (2014)

The occurrence of multiple failures and not the maximum productivity can be caused by a low competence and behavior of worker dissatisfaction in work. Based on data collected authors, who will be given a training program has been organized and scheduled, but participants who will participate in training activities were selected randomly to avoid activities that coincide or clash with other activities such as services to the drilling location. Most of the workers complained of the same problem is felt less satisfied with the existing conditions, the workers concerned are given training materials are still not quite fit or do not fit with what they need in their work, they actually expect that the problems they face in his work can be found in the training solution.

In addition to issues concerning the training, workers complained of lack of motivation given the company against them, they assume the company still has not provided the optimal needs such as salaries not in accordance with the given workload and promotions are still rare. Another phenomenon that can cause problems is that some workers were found not to be in place during working hours, there are also workers who often come too late.

\section{Literature}

Luthans (2005) in his book Organizational Behavior, job satisfaction is a positive emotional state of a person arising from the appreciation of any work that has been done. It says further that job satisfaction is the result of one's achievement towards to how well his job to provide something useful for him. 
Robbins (2003) defines job satisfaction as a general attitude towards one's job, the difference between the amount of reward received by a worker and the amount that they believe they should receive. Employees who enjoy the work will be satisfied if the result of hard work and remuneration is considered fair and reasonable (Fathoni, 2006).

According Malthis (2006) job satisfaction is a positive emotional state of a person evaluate work experience. Job dissatisfaction arises when these expectations are not met. Job satisfaction has many dimensions, in general is the satisfaction in the work itself, salary, recognition, relationships between supervisors with labor, and the opportunity to move forward.

Each dimension generates an overall feeling of satisfaction with the work itself. Benchmark level of satisfaction that absolutely no, because every individual is different employee satisfaction standards. Indicators of job satisfaction can be measured by the discipline, morale, and labor turnover is small, it is relatively good employee satisfaction but on the contrary if the discipline, morale and labor turnover is large, then the job satisfaction of employees in companies considered less.

One of the variables that influence satisfaction is the training, according to Mathis (2002), training is a process by which people attain a certain ability to help achieve organizational goals. Therefore, the process is tied to the various objectives of the organization, the training can be seen in a narrow or broad. Limited basis, providing training employees with specific knowledge and skills that can be known and used in their current job. Sometimes there are limits drawn between training and development, the development of which are broader in scope and focus on the individual to achieve new capabilities useful both for work today and in the future.

Understanding motivation to work according to Danang Sunyoto (2013) is a state that encourages the desire of individuals to undertake certain activities to achieve his wish. Motivation from oneself is the force that will realize a behavior in achieving the purpose of satisfaction itself on the specific type of activity, and a positive direction with the lead approaching the object of which is the goal.

Siagian (2002: 106) put forward in the development of the concepts of motivation, has developed theories of motivation that can provide an explanation of the motivation of the members of the organization's work, ranging from motivational theory as the theory of hierarchy of needs of Maslow, Theory $X$ and $Y$ by Mc Gregor, 7 Hygiene motivation theory by Herzberg, the theory of Existence, relatedness, and Growth (ERG) of Al defer, the theory needs of Mc Clelland which all starts from the needs of the individual.

David McClelland (Robbins, 2001: 173) in his theory Mc.Clelland's Achievement Motivation Theory or achievement motivation theory McClelland also be used to support the hypothesis that will be presented in this study. In theory McClelland argued that the individual has a potential energy reserves, bagamana this energy is released and developed tergatung on the strength or encouragement of individuals and situations as well as the opportunities available. This theory focuses on three needs: the need for achievement (achievement), power requirements (power), and the need for affiliation. Model of motivation is found in various lines of the organization, both staff and managers. Some employees have a character that is a blend of the motivation models.

David McClelland known for explaining the three types of motivation, which is identified in the book "The Achieving Society":

1. Motivation for achievement (n-ACH)

2. Motivation for power (n-pow)

3. Motivation for affiliated / friends (n-affil)

McClelland said that most people have a combination of these characteristics, the result would be influence behavior of employees in work or managing the organization.

Furher, David McClelland (Mangkunagara, 2005: 68) points out of 6 (six) indicator motiasi people who have high achievement, namely: (1) Has the level of personal responsibility is high, (2) Dare to take and bear the risk, (3) Having a goal realistic, (4) Having a thorough work plan and strive to realize the goals, (5) Utilizing feedback concrete in all activities undertaken, and (6) for a chance to realize the plans that have been programmed. Many companies believe that revenues, salaries are the main factors that influence employee satisfaction. So when the company was already providing sufficient salary, companies feel that employees are satisfied, but there are many factors that can give satisfaction to the employees including the provision of training and various other motivations.

Based on the above description of the relationship between variables and support previous research described as follows: 


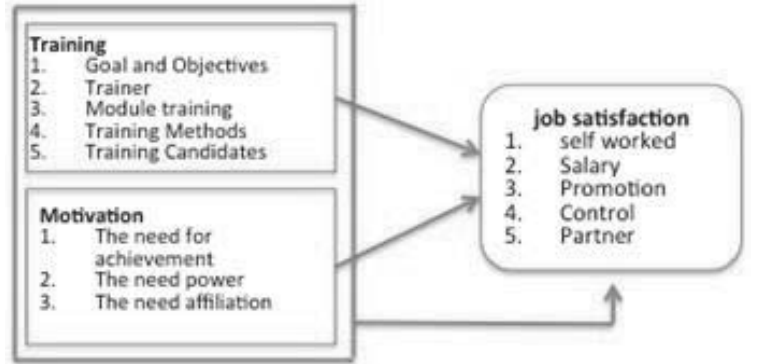

Figure 2. Framework of research

Based on literature review, and the existing framework hypothesis can be formulated as follows:

$\mathrm{H} 1$ : There is a significant relationship between job satisfaction employee training to discover the function of the PT. Pertamina EP.

$\mathrm{H} 2$ : There is a significant relationship between motivation to explore the function of employee job satisfaction PT. Pertamina EP.

H3: There is a significant relationship between training and motivation simultaneously to discover the function of workers job satisfaction PT. Pertamina EP.

\section{Research Method}

This type of research by the authors is descriptive quantitative analysis, quantitative in the sense that in this study performed statistical tests, which measure how much particular connection or the power relationship between the variables studied variables. Umar in his book (2007) said that the associative causal research is describing a causal relationship or influence of one variable with another variable. In other words, the design is useful to measure the causal relationships between variables or to analyze how one variable affects another variable.

Total sample of 55 people selected using random sampling methods calculated using the formula Slovin than 112 workers Exploration function PT. Pertamina EP headquarters in Jakarta (2014). Data was collected by questionnaires, observations and interviews. The research instrument uses a Likert scale with a scale of $1-5$. Techniques of analysis using simple regression analysis and multiple linear regression using SPSS 20.0 for windows. Test instrument validation is done by counting the value of the product moment correlation of each of the questions and the result is that from 36 the questions 34 the questions are valid. Reliability testing conducted in the questionnaire by calculating the coefficient alpha values of all variables and all variables obtained results show values above 0.70 which means that all variables are reliable.

\section{Result And Discussion}

\subsection{Analysis Influence of Training to Workers Job Satisfaction}

The following is a translation of the results from the calculation of the regression coefficients, while the details of the details of the calculations are summarized in Table 3 below:

Table 3. Recap Variable Analysis Training on Job Satisfaction

\begin{tabular}{|c|c|c|c|c|}
\hline Variabel & Standarized & $\begin{array}{c}\mathrm{t} \\
\text { Count }\end{array}$ & Sign t & \multirow[t]{2}{*}{ Descp } \\
\hline & Coefisien beta & & & \\
\hline $\mathrm{X} 1$ & .496 & 5.331 & 0.000 & Sig \\
\hline $\begin{array}{l}\text { Variable terik } \\
\text { Constant : } 1 . \\
\mathrm{R}: .591 \\
\text { R square (R) } \\
\text { Adjusted R S } \\
\text { t hitung : } 5.3 \\
\text { Sign F : .000 }\end{array}$ & : 337 & & & \\
\hline
\end{tabular}

Source: Research Data Processing (2015) 
Based on the results of the analysis can be structured simple linear regression model are as follows:

$$
Y=1,667+0,496 \times 1
$$

Constants $(\beta 0)$ : Constant value $(\beta 0)$ of 1.667 , which means that if there is no training variable $(X 1)$ then the tendency will be the same as the constants of the regression models is equal to 1.667 or less expressed satisfaction scores. Coefficient ( $\beta 1$ ): regression coefficient ( $\beta 1)$, amounting to 0.496 which means that the training variables affect the job satisfaction at the level of Sig. $0.000>0.05$, in other words training become a strong driving factor in increasing the quantity of job satisfaction that occurred in the function of Exploration PT. Pertamina EP. In other words Function Exploration Workers of PT Pertamina EP when given the proper training and appropriate will have an increased level of satisfaction. Simple regression test results to obtain the value of the coefficient of determination (R square) of: $34.9 \%$ can be shown by Table 3 Coefficient of determination (R square) shows that (X1) can improve job satisfaction $(Y)$ of $34.9 \%$, while the remaining $65,1 \%$ is influenced by other variables not examined. If the sig. $<5 \%$, then a significant influence. But if sig. $>5 \%$ or 0.05 , it has no effect. The result $(0.000>0.05)$, so it can be stated that the first hypothesis is training real impact on job satisfaction, so the hypothesis that the first estimate otherwise unacceptable.

\subsection{Effect Analysis on Job Satisfaction Motivation Worker}

Simple linear regression analysis is used to determine the influence of motivation (X2) on Job Satisfaction $(Y)$ results of data analysis using simple linear regression analysis.

Table 4. Recap Motivation Variables Analysis on Job Satisfaction

\begin{tabular}{|c|c|c|c|c|}
\hline Variabel & Standarized & T hitung & Sign $t$ & \multirow{2}{*}{ Ket } \\
\hline & Koefisien beta & & & \\
\hline $\mathrm{X} 2$ & .342 & 3.431 & 0.001 & Sig \\
\hline \multicolumn{5}{|c|}{$\begin{array}{l}\text { Variable terikat Y } \\
\text { Constant : } 2.064 \\
R: \text { : } 426 \\
R \text { square }(\mathrm{R}): .182 \\
\text { Adjusted R square : .166 } \\
\text { t hitung : } 3.431 \\
\text { Sign } F: .001\end{array}$} \\
\hline
\end{tabular}

Source: Research Data Processing (2015)

The calculations were done with SPSS v. 20 in full can be found in the appendix and the results are summarized in Table 4. based on the results of the analysis can be structured simple linear regression model as follows:

$Y=2.064+0,342 X_{2}$

Constants ( $(\beta 0)$ : Constant value $(\beta 0)$ of 2.064 , which means that if there is no motivation variable $(X 2)$, the tendency will be the same as the constants of the regression models is equal to 2.064 or less expressed satisfaction scores.

Coefficient ( $\beta 2$ ): regression coefficient ( $\beta 2)$, amounting to 0.342 which means that the variable motivation affect the job satisfaction at the level of Sig. 0.001>0.05, in other words a factor driving motivation strong enough to increase the quantity of job satisfaction that occurred in the function of Exploration PT. Pertamina EP. In other words Function Exploration Workers of PT Pertamina EP when given the motivation would have increased the level of satisfaction.

Simple regression test results to obtain the value of the coefficient of determination (R2) of: $18.2 \%$ can be shown by Table 4 Coefficient of determination (R2) shows that $(X 2)$ can improve job satisfaction ( $Y$ ) of $18.2 \%$, while the remaining $81,8 \%$ are influenced by other variables not examined.

If the sig. $<5 \%$, or 0.05 , a significant effect. But if sig. $>5 \%$ or 0.05 , it has no effect. The result is $0.001<0.05$, so it can be stated that the second hipotessis where motivation $(\mathrm{X} 2)$ effect on job satisfaction $(\mathrm{Y})$ was convicted.

\subsection{Regression coefficient calculation}

Multiple linear regression analysis was used to determine the effect Training (X1), motivation (X2) on Job Satisfaction (Y). The results of data analysis using multiple linear regression analysis that the calculations are complete can be seen in the appendix and the results are summarized as follows in Table 5. 
Table 5. Recap Variable Analysis Training on Job Satisfaction

\begin{tabular}{|l|c|c|c|c|}
\hline \multicolumn{1}{|c|}{ Variabel } & Standarized & $\begin{array}{c}\mathrm{t} \\
\text { Count }\end{array}$ & \multirow{2}{*}{ Sign t } & \multirow{2}{*}{ Descp } \\
\hline \multicolumn{1}{|c|}{ Coefisien beta } & & & \\
\hline \multicolumn{1}{|l|}{$\mathrm{X} 2$} & .420 & 4.088 & 0.000 & Sig \\
\hline Variable terikat Y (Kepuasan Kerja) & 1.630 & 0.109 & \\
Contant :1.366 \\
$\mathrm{R}: .617$ \\
$\mathrm{R}$ square (R): .381 \\
Adjusted R square : .357 \\
F hitung: 15.986 \\
Sign F : .000
\end{tabular}

Source: Research Data Processing (2015)

Based on the results of the analysis can be composed of multiple linear regression model as follows:

$$
Y=1,366+0,420 X_{1}+0,160 X_{2}
$$

Constants $(\beta 0)$ : Constant value $(\beta 0)$ amounted to 1,366 , which means that if there is no increase or a reduction in the variable Training (X1); Motivation (X2), the tendency will be the same as the constants of the regression models is equal to 1.366 or less satisfaction scores.

Coefficient ( $\beta 1)$ : regression coefficient $(\beta 1)$, amounting to 0.420 which means that the variables affect the job satisfaction training at the level of Sig. 0.000>0.05, in other words training has no effect if there is a change in her job satisfaction. The changes show that the training held company into a variable that has a greater influence than the other independent variable (Motivation)

Coefficient ( $\beta 2$ ): regression coefficient ( $\beta 2)$, amounting to 0.160 which means that the variable motivation affect the job satisfaction of workers at the level of sig. $0.109>0.05$. In other words, at this moment that became the deciding factor in job satisfaction is training workers. By increasing or increasing good training conducted will provide a good impact on job satisfaction increasing workers.

Results of testing to obtain the coefficient of determination (R square) of 0.357 . The coefficient of determination ( $R$ square) showed that training (X1) and motivation (X2) is able meningatkan Job Satisfaction (Y) of $35.70 \%$, while $64.30 \%$ are influenced by other variables not examined.

Or in another sense, that variations Workers Job Satisfaction $(Y)$ can be explained by the variation of the independent variable, namely Training (X1) and motivation (X2) amounted to $35.70 \%$. While the rest $(100 \%-35.70 \%=$ $64.30 \%$ ) is explained by other causes beyond models such as variable work environment, Discipline, Turnover, leadership and others.

\subsection{Uji F}

To examine the relationship simultaneously training variable (X1) and motivation (X2) against workers' job satisfaction (Y). F count testing done in comparison with table F. ANOVA table above indicates that the regression are statistically significant with a statistical test $F=15.986$ with a level of 0.000 . Because of the significance probability is less than 0.05 , the regression model can be used to predict changes in job satisfaction $(Y)$ or say that variable $X 1$ and $X 2$, jointly influence on the variable $Y$. Thus the third hypothesis has been verified and found to be acceptable, namely that the training factor $(\mathrm{X} 1)$ and motivation $(\mathrm{X} 2)$ are all factors that influence job satisfaction $(\mathrm{Y})$ on the functioning of Exploration PT Pertamina EP.

\subsection{Inter-Dimensional Correlation Matrix}

Correlation matrix between the dimensions of the dependent with the independent used to examine which is the most powerful influence on the dimensions of the independent variable on the dependent variable. 
Table 6. Correlation Matrix of Inter-Dimensional

\begin{tabular}{|c|c|c|c|c|c|c|}
\hline \multirow[t]{2}{*}{ Variabel } & \multicolumn{6}{|c|}{ Y (Work Satisfaction) } \\
\hline & Dimension & \begin{tabular}{|c|} 
Y1 \\
(Self Worked)
\end{tabular} & Y2 (Salary) & $\begin{array}{c}\mathrm{Y} 3 \\
\text { (Promotion) }\end{array}$ & $\begin{array}{c}\text { Y4 } \\
\text { (Control) } \\
\end{array}$ & $\begin{array}{c}\text { Y5 } \\
\text { (Partner) }\end{array}$ \\
\hline \multirow{5}{*}{ 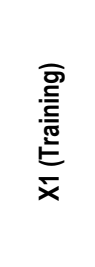 } & X11 (Goal and objectives training) & .578 & .335 & $.343^{*}$ & -.034 & .225 \\
\hline & X12 (Trainer) & .394 & .076 & .207 & $.387^{\text {t* }}$ & .250 \\
\hline & X13 (Module Training) & .652 & .359 & .236 & -.003 & $.374^{* *}$ \\
\hline & X14 (Metode Training) & $.513^{*+}$ & .354 & .213 & .063 & $.498^{* *}$ \\
\hline & X15 (Candidates Training) & $.482^{* *}$ & .171 & .123 & -.127 & .201 \\
\hline \multirow{3}{*}{ 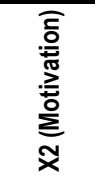 } & X21( The need for achievement) & $.338^{*}$ & .171 & -.106 & .002 & .574 \\
\hline & X22( The need for power ) & $.442^{* *}$ & .159 & .251 & -.076 & $.522^{* *}$ \\
\hline & X23( The need for affiliation ) & $.410^{* *}$ & .159 & .023 & .153 & .539 \\
\hline
\end{tabular}

Source: Research Data Processing (2015)

Relationship between Dimensions Variable Training (X1) on Job Satisfaction Workers (Y). The relationship between the dimensions of the independent variable on the dependent variable are almost entirely has a positive and significant relationship. Explanation in Table 6 above shows that the relationship between the dimensions of training materials to the dimensions of work itself in the variable job satisfaction because it has the highest coefficient is equal to 0652 (having a relationship that is "Strong").

Dimensions variable relationship between motivation (X2) on Job Satisfaction Workers (Y). The relationship between the dimensions in the independent variable on the dependent variable are almost a whole has a positive and significant relationship. In Table 6 above shows that the relationship between the dimensions of need for achievement (nAch) to the dimensions of coworkers have the highest coefficient value is equal to 0.574 (has a relationship "Strong").

\section{Discussion of Results}

\subsection{Influence Training on Job Satisfaction}

Based on the results of data processing, it can be concluded that the training positively and significantly (real) on Job Satisfaction Workers at a significance level $(a=0 \%)$, so that the level of $a=5 \%$ Training definitely positive and significant impact on job satisfaction Workers. The value of R Square shows that $34.9 \%$ of the variance "Training" can be explained by changes in variable Workers Job Satisfaction. While the rest influenced by other factors such as work environment, Discipline, Turnover, leadership and others.

The most powerful dimension is the dimension of training materials related to the dimension of the Individual Work on Workers' Job Satisfaction variable because it has a coefficient $=0652$. (Have a relationship that is "Strong"). So it can be interpreted that the worker in function eksporasi PT Pertamina EP expects that the training material is adjusted to the needs of workers in carrying out the work itself. Appropriate training materials are where the work is being done everyday, when experiencing problems or difficulties in the operations and in the limited scientific shortcomings into material or material that will be covered in the training to look for solutions to existing problems, so that workers can perform the job optimally and the serious effect of increased satisfaction in their work.

And of some existing training dimension, there is a relationship which resulted in negative value (-), whereby if the increasing quality of the goals and objectives of training, training materials, and the ability of trainees that follow, the surveillance of superiors increasingly unnecessary because workers can do the job independently and be able to take the best decisions without having to rely on their supervisor or boss. 


\subsection{Influence Motivation on Job Satisfaction}

Motivation positive and significant impact (real) on Job Satisfaction Workers at a significance level ( $\alpha=0.001$ or $0.1 \%$ ), so that the level of $a=5 \%$ Motivation certainly positive and significant impact on job satisfaction Workers. The value of $R$ Square shows that $18.2 \%$ of the variance "Motivation" can be explained by changes in variable Workers Job Satisfaction. While the rest influenced by other factors such as work environment, Training, Discipline, Turnover, leadership and others.

The most powerful dimension of the relationship is a need to excel Dimension (N-Ach) against dimension Colleagues at variable Workers Job Satisfaction for having coefficient $=0.574$ (have a relationship that is "Strong"). So that workers can be interpreted in function of Exploration PT Pertamina EP has a high need for achievement and the achievements they will feel the satisfaction that the satisfaction derived from their co-workers were pleasant due to competition and healthy workplace in working environment healthy.

A healthy working environment and a pleasant arising from the appreciation of colleagues on this achievement by a worker. Coworkers who excel can help facilitate in resolving the existing problems in the work performed other workers. This makes the workers feel satisfied in doing the job.And of some dimensions of motivation that exist, there is a relationship which produces a negative value (-), which is where if the increasing need for achievement and power in the company, the promotion and supervision of getting unneeded or reduced, it may be possible because of the feeling of going concerns against their superiors who feel unrivaled and fear of losing positions with the emergence of workers who have a spirit of achievement and high power. Senior so they do not want to provide oversight and promotion of their subordinates.

Motivation positive and significant impact (real) on Job Satisfaction Workers at a significance level $(a=0.001$ or $0.1 \%$ ), so that the level of $a=5 \%$ Motivation certainly positive and significant impact on job satisfaction Workers. The value of R Square shows that $18.2 \%$ of the variance "Motivation" can be explained by changes in variable Workers Job Satisfaction. While the rest influenced by other factors such as work environment, Training, Discipline, Turnover, leadership and others.

The most powerful dimension of the relationship is a need to excel Dimension (N-Ach) against dimension Colleagues at variable Workers Job Satisfaction for having coefficient $=0.574$ (have a relationship that is "Strong"). So that workers can be interpreted in function of Exploration PT Pertamina EP has a high need for achievement and the achievements they will feel the satisfaction that the satisfaction derived from their co-workers were pleasant due to competition and healthy workplace in working environment healthy.

A healthy working environment and a pleasant arising from the appreciation of colleagues on this achievement by a worker. Coworkers who excel can help facilitate in resolving the existing problems in the work performed other workers. This makes the workers feel satisfied in doing the job.

And of some dimensions of motivation that exist, there is a relationship which produces a negative value (-), which is where if the increasing need for achievement and power in the company, the promotion and supervision of getting unneeded or reduced, it may be possible because of the feeling of going concerns against their superiors who feel unrivaled and fear of losing positions with the emergence of workers who have a spirit of achievement and high power. Thus, Senior they do not want to provide oversight and promotion of their subordinates.

\subsection{Training and Motivation Influence on Job Satisfaction}

Training and Motivation simultaneously positive and significant (real) on Job Satisfaction Workers at a significance level $(\alpha=0 \%)$ for variable and Training ( $\alpha=0.109$ or $10.9 \%)$ for motivation variable, so at the level of $\alpha=5 \%$ Training and Motivation certainly positive and significant impact on job satisfaction Workers. In other words, at this moment that became the deciding factor in job satisfaction is training workers. The value of $\mathrm{R}$ Square shows that $35.7 \%$ of the variance "Training and Motivation" can be explained by changes in variable Workers Job Satisfaction. Whereas the rest influenced by other factors such as work environment, Discipline, Turnover, leadership and others that are not described in this study. This shows that job satisfaction of workers affected by factors mastery of skills, knowledge and attitudes as well as the fulfillment of the need to achieve the expected level of satisfaction. These efforts should be supported by the company in providing the opportunity for workers to learn and improve.

\section{Conclusion}

After analyzing the results of the research, it was concluded as follows: 
1. Hypothesis "Training a positive and significant impact on job satisfaction of workers" acceptable. For variable training, the most powerful dimension is the dimension of training materials related to the work itself in variable worker job satisfaction.

2. Motivation positive and significant impact on job satisfaction Function Exploration PT. Pertamina EP pales motivation increases, employee job satisfaction will also increase, otherwise if motivation decreases, then the job satisfaction of workers will also be decreased.

3. Training and motivation jointly significant effect on employee job satisfaction Function Exploration.

\section{References}

Handoko, T Hani. (2008). Manajemen Personalia \& Sumberdaya Manusia. Yogyakarta: BPFE Yogyakarta.

Hasibuan, S.P Malayu. (2010). Manajemen Sumber Daya Manusia. Jakarta: Bumi Aksara.Luthans, Fred. (2006). Perilaku Organisasi, (Alih Bahasa V.A Yuwono, dkk),Edisi Bahasa Indonesia, Yogyakarta: ANDI.

Mangkunegara, A.A Anwar Prabu. (2009). Manajemen Sumber Daya Manusia Perusahaan. Bandung: PT. Remaja Rosdakarya.

Noe, R.A, Hollenbeck J.R. Gerhart,B., Wright, P. (2010). Human Resources Management: Gaining A Competitive Advantage. Mc GrawHill. USA.Robbins, Stephen P. (2003). Perilaku Organisasi. Jakarta : PT. Indeks Kelompok Gramedia.

Sunyoto, Danang. (2013). Teori, Kuisioner, Dan Proses Analisis Data Perilaku Organisasional. Yogyakarta: CAPS Yogyakarta

Sugiyono. (2009). Metode Penelitian Kuantitatif Kualitatif dan R \& D. Bandung: Alfabeta. 